\title{
Estimation of atmospheric iodine emission from coal combustion
}

\author{
D. Wu $\cdot$ J. Du $\cdot$ H. Deng $\cdot$ \\ W. Wang $\cdot$ H. Xiao $\cdot$ P. Li
}

Received: 4 June 2012/Revised: 19 December 2012/Accepted: 22 January 2013/Published online: 19 February 2013

(C) Islamic Azad University (IAU) 2013

\begin{abstract}
Coal combustion is the primary anthropogenic source of atmospheric iodine, which has important environmental and health effects. The iodine distribution in Chinese coals and the atmospheric iodine emission factors of coal-fired boilers are studied to estimate the iodine atmospheric flux from coal combustion in China from 1995 to 2009. The national average iodine content weighted by coal yield fluctuated from $2.61 \mathrm{mg} \mathrm{kg}^{-1}$ in 1995 to $2.09 \mathrm{mg} \mathrm{kg}^{-1}$ in 2009 , recording an annual decline of $1.42 \%$. By establishing a monitoring program, iodine distribution in coal by-products after the coal is consumed in combustors is measured, and atmospheric iodine emission factors by sectors are calculated. Based on the coal consumption by sectors, the annual atmospheric iodine emission from coal combustion in China increased at an annual rate of $4.3 \%$ from 3031.1 tons in 1995 to 4872.6 tons in 2009. Anthropogenic atmospheric iodine emission is significantly underestimated, and its environmental and health effects must be given more attention.
\end{abstract}

Keywords Anthropogenic source - Atmospheric flux · Coal consumption $\cdot$ Emission factors

\section{Introduction}

Iodine is an essential nutritional element for all mammals. The lack of dietary iodine intake can lead to iodine

D. Wu $\cdot$ J. Du $\cdot$ H. Deng $\cdot$ H. Xiao $\cdot$ P. Li

School of Environmental and Chemical Engineering,

Nanchang University, 330031 Nanchang, P.R. China

D. Wu $(\bowtie) \cdot$ W. Wang

Institute of Geographic Sciences and Resources Research,

CAS, 100101 Beijing, P.R. China

e-mail: dswu@ncu.edu.cn deficiency disorders (IDDs). The oceans represent the largest reservoir of iodine on earth, with most of the atmospheric iodine originating from the volatilization of iodine from oceans (Fuge and Johnson 1986; Fuge 1990; Whitehead 1984). Atmospheric iodine is of great importance in the geochemical cycle, wherein it is transferred to the terrestrial environment by means of wet and dry depositions (Fuge and Johnson 1986; Fuge 1990). Atmospheric precipitation is considered the major contributor of terrestrial iodine, and may therefore have a direct influence on the prevalence of IDDs (Fuge 1996). Evidence demonstrated that many Chinese residents in IDD areas no longer suffered from iodine deficiency disease because of getting iodine from coal combustion (Finkelman 2007; Wang et al. 2005).

Owing to its environmental significance, atmospheric iodine chemistry has received increasing attention in recent years (Baker 2005; Carpenter 2003; Jones et al. 2010; Mahajan et al. 2009; Saiz-Lopez and Plane 2004; Saiz-Lopez et al. 2012). Atmospheric iodine is active in destructing $\mathrm{O}_{3}$ and $\mathrm{H}_{\mathrm{x}} \mathrm{O}_{\mathrm{y}}$ free radicals, enhancing the $\mathrm{NO}_{2} / \mathrm{NO}$ ratio, and formatting cloud condensation nuclei, and perhaps influences the earth's albedo; hence, it has an important role in global climate change (Alicke et al. 1999; Baker 2005; Carpenter 2003; Chameides and Davis 1980; Davis et al. 1996; Jenkin et al. 1985; Jones et al. 2010; Mahajan et al. 2009; Saiz-Lopez and Plane 2004; Solomon et al. 1994).

Among many types of anthropogenic iodine emissions, the major source is fossil fuel combustion (Bettinelli, et al. 2002; Fuge and Johnson 1986; Fuge 1990; Landsberger et al. 1989; Whitehead 1984). Fossil fuel combustion is heavily concentrated in and around industrial cities that have the highest population density. In contrast, natural marine emissions are dispersed from the outset over a 
wide geophysical area. Hence, anthropogenic release of atmospheric iodine may have greater influence on the environment and human health in heavily populated inland regions; however, these emissions are believed to be negligible on a global scale compared to the natural marine emission. This was proven by the research of Zhu and Tan (1988): rainwater samples collected from a $1,500 \mathrm{~km}$ range of coastal to central continental areas in the direction of the monsoon in China, showed no significant decline in iodine concentration, whereas iodine content in the atmosphere was higher around urban centers than in rural areas.

Atmospheric iodine released from fossil fuel combustion is estimated to be 400 tons per year, which is approximately $0.04 \%$ of the total amount of iodine transferred annually to and from the atmosphere, namely $1 \mathrm{Tg}$ (Saiz-Lopez et al. 2012). However, this estimation is misleading because it uses incorrect data for the average iodine content of coal and the emission factor of iodine into the atmosphere. The average iodine content in coal around the world is $4 \mathrm{mg} \mathrm{kg}^{-1}$, according to a study by Block and Dams (1973) (Chameides and Davis 1980; Whitehead 1984). In their study, Block and Dams (1973) analyzed 15 Belgian coal samples and only reported the range of iodine in these samples to be $1-4 \mathrm{mg} \mathrm{kg}^{-1}$, not the average value of $4 \mathrm{mg} \mathrm{kg}^{-1}$. Meanwhile, the atmospheric iodine emission factor during coal combustion of $5 \%$ was adopted (Whitehead 1984), which is the emission factor for heavy metals (such as $\mathrm{Cu}$ and $\mathrm{Zn}$ ) (Bertine and Goldberg 1971); however, since iodine is more volatile, its emission rate is much higher than $5 \%$ after coal combustion.

Coal is the major fossil fuel used in China, the world's largest coal-mining and -consuming country. In 2009, nationwide production totaled 2,965 Mt, approximately $45.6 \%$ of the world total, whereas consumption totaled 3,068 Mt, approximately $46.9 \%$ of the world total (British Petroleum 2010). Therefore, coal combustion has a significant effect on atmospheric iodine concentration within China. Residents receive excessive iodine from the open combustion of coal indoors; therefore, coal combustion affects IDD distribution in the country (An et al. 1997; Yang et al. 2000).

However, an extensive and detailed research on atmospheric iodine emissions from coal combustion has not yet been conducted. In this paper, we report on the iodine content of coal in China, as well as the atmospheric iodine emission factors in the coal combustion process. Together with coal consumption, we estimate the atmospheric iodine emission from all types of sectors in China. In addition, we also investigate atmospheric iodine emission from coal combustion from 1995 to 2009.

\section{Materials and methods}

Coal samples for determining iodine content of coals mined by each province

Our nationwide sampling program was designed according to coal resources, coal yield, coal rank, and coal-forming periods (Wu et al. 2008). Using the national standard GB 481-93 (State Bureau of Technical Supervision 1993), we collected 305 coal samples from the major coal mines of 26 provinces, autonomous regions, and municipalities in China.

Samples for determining atmospheric iodine emission factors by each coal-consuming sector

Atmospheric iodine emission factors depend greatly on the coal combustion technology and the emission control device. The main boiler types are the pulverized coal-fired boilers, grate-fired boilers, fluidized-bed boilers, and domestic coal stoves. For the emission control device, only those for particulate matters (PMs) have been widely applied in boilers. In addition, the flue gas desulfurization (FGD) system began to be installed in power plants in the mid-1990s to reduce $\mathrm{SO}_{2}$ emission. The dominant PM control technologies for coal combustion in China include electrostatic precipitators (ESPs), wet dust collectors, and cyclones. In view of the current status of coal combustors equipped with emission control devices in China, a sampling program was designed.

Samples of feed coal from the representative boilers equipped with typical emission control devices for $24 \mathrm{~h}$ were collected in Anqing and Huainan in Anhui Province and in Nanchang, Fengcheng, and Pingxiang in Jiangxi Province. The collection process was performed every $4 \mathrm{~h}$, obtaining six different samples that were then mixed together and homogenized to yield a single sample. The combustion by-products were also collected simultaneously with the feed coal. Thus, six different samples of the slag from the slag tap of the boiler and of the fly ash from the hoppers of the PM control equipment were collected, mixed together, and homogenized. Likewise, samples of FGD gypsum, together with the limestone slurry used in the desulfurization process, were collected. In accordance with the Chinese national standard GB/T16157-1996 (SEPA 1996 and SBTS 1996), samples of the flue gas were collected simultaneously at the inlet and outlet of the PM control equipment to study the efficiency of the dust cleaner.

Samples of feed coal and coke were collected in a coke plant in Pingxiang, Jiangxi Province. Samples of feed coal and cinder were collected in a gasworks in Nantong, Jiangsu Province. The sampling procedure in the coke plant and gasworks was the same as that in boilers. 
Coal, coal-clay, and honeycomb briquette are consumed in the domestic coal stoves without the use of any PM control device. These samples and their corresponding cinder were collected in Bijie, Guizhou Province; Nanchang and Pingxiang, Jiangxi Province; and Huainan and Anqing, Anhui Province.

Sample preparations were conducted according to the Chinese national standard GB 474-1996 (SBTS 1996). The samples were prepared by air-drying, grinding, and sorting through a 200-mesh nylon sieve.

The amount of daily feed coal and its corresponding combustion by-product, as well as limestone slurry and FGD gypsum, was observed for material balance during the sampling process.

Determination of iodine content in samples and ash yield in coals

Catalytic spectrophotometry, combined with pyrohydrolysis, was used for determining the iodine content of all samples. The analytical method used in this study was published in our previous paper (Wu et al. 2007, 2008). The accuracy was confirmed by evaluating the recovery in coal samples spiked with Chinese soil reference materials (SMRs) that have standard iodine contents. Ten concentration levels were tested $\left(0.04-8.69 \mathrm{mg} \mathrm{kg}^{-1}\right)$ and the recoveries were in the range of $89.9-109.6 \%$; the reproducibility of measurement was less than \pm 9.52 and $\pm 25 \%$ as to coals with iodine content over $0.30 \mathrm{mg} \mathrm{kg}^{-1}$ and that below $0.25 \mathrm{mg} \mathrm{kg}^{-1}$, respectively.

The ash yields of coals were measured according to ASTM method D3174-93 (ASTM 1993).

Determination and calculation of atmospheric iodine emission factors and annual atmospheric iodine emission flux

The iodine emission factor $e_{\mathrm{f}}$ (into fly ash) can be calculated following Eq. 4:

$e_{\mathrm{f}}=Q_{\text {ash }} / Q_{\text {total }}$

$Q_{\text {ash }}=C_{\text {ash }} \times M_{\text {coal }} \times A_{\mathrm{f}} \times F_{\mathrm{f}} \times \eta$

$Q_{\text {total }}=C_{\text {coal }} \times M_{\text {coal }}$

where $e_{\mathrm{f}}$ is the emission factor of iodine into fly ash (\%); $Q_{\text {ash }}$ is the amount of iodine into fly ash in the combustion process (mg); $Q_{\text {total }}$ is the total iodine in coal (mg); $C_{\text {coal }}$ is the iodine content of coal $\left(\mathrm{mg} \mathrm{kg}^{-1}\right)$; and $C_{\text {ash }}$ is the iodine content of fly ash $\left(\mathrm{mg} \mathrm{kg}^{-1}\right)$. Here, $M_{\text {coal }}$ is the mass of coal $(\mathrm{kg}) ; A_{\mathrm{f}}$ is the ash content of coal (\%); $F_{\mathrm{f}}$ is the ratio of the amount of ash into flue gas to the sum of ash; and $\eta$ is the efficiency of dust remover (\%). Substituting Eqs. 2 and 3 into Eq. 1 yields the following:

$e_{\mathrm{f}}=C_{\text {ash }} \times A_{\mathrm{f}} \times F_{\mathrm{f}} \times \eta / C_{\text {coal }}$

According to the conservation of mass, the relationship among the emission factors is as follows:

$e_{\mathrm{f}}+e_{\mathrm{s}}+e_{\mathrm{a}}+e_{\mathrm{g}}=1$

where 1 refers to the total emission amount of the element; $e_{\mathrm{S}}$ is the ratio of iodine in slag $(\%) ; e_{\mathrm{a}}$ is the atmospheric iodine emission factor that equals the ratio of the iodine released into the atmosphere (\%); and $e_{\mathrm{g}}$ refers to the ratio of the iodine captured by FGD gypsum (\%). All parameters in Eq. 4 were measured directly; $e_{\mathrm{s}}$ and $e_{\mathrm{g}}$ were measured using a similar method, with the iodine from the limestone slurry subtracted from FGD gypsum when $e_{\mathrm{g}}$ is measured. Then, $e_{\mathrm{a}}$ can be easily calculated from Eq. 5 .

Iodine emissions are calculated using consumption data and detailed iodine emission factors. The annual atmospheric iodine emission flux from coal combustion is described by the following equation:

$E_{\mathrm{t}}=\sum_{i}\left(e_{\mathrm{a}, \mathrm{i}} \times C_{\text {coal }} \times M_{\text {coal }, \mathrm{i}}\right)$

where $E_{\mathrm{t}}$ is the atmospheric iodine emission from coal combustion; $e_{\mathrm{a}, \mathrm{i}}$ is the atmospheric iodine emission factor for sector $i ; M_{\text {coal, }}$ is the annual coal consumption; and $i$ is the sector.

\section{Results and discussion}

Iodine content of coal in China

Table 1 lists the iodine content of raw coal mined in China by province.

We assumed that the iodine content of raw coal as produced did not change at the provincial level during 1995-2009. Weighted by the coal yield of each province (NBS 1998, 2001, 2004-2008, 2010), the national average iodine content decreased from $2.61 \mathrm{mg} \mathrm{kg}^{-1}$ in 1995 to $2.49 \mathrm{mg} \mathrm{kg}^{-1}$ in 1997 , recovered to $2.54 \mathrm{mg} \mathrm{kg}^{-1}$ in 1998 , decreased to $2.36 \mathrm{mg} \mathrm{kg}^{-1}$ in 2000 , rebounded to $2.51 \mathrm{mg} \mathrm{kg}^{-1}$ in 2001, and thereafter decreased continuously, measuring $2.09 \mathrm{mg} \mathrm{kg}^{-1}$ in 2009 .

Iodine distribution in by-products after coal combustion

The iodine distribution for 1 ton of coal combusted in each type of boiler equipped with different emission control devices is listed in Table 2. 
Table 1 Iodine content of raw coal mined in China by province $\left(\mathrm{mg} \mathrm{kg}^{-1}\right)$

\begin{tabular}{|c|c|c|c|c|}
\hline Province $^{a}$ & Range & Mean & $\begin{array}{l}\text { Geometric } \\
\text { mean }\end{array}$ & $\begin{array}{l}\text { Number of } \\
\text { samples }\end{array}$ \\
\hline Anhui & $0.41-4.70$ & 1.40 & 1.04 & 11 \\
\hline Beijing & - & 0.38 & - & 1 \\
\hline Chongqing & $3.54-9.31$ & 7.50 & 7.17 & 8 \\
\hline Fujian & $0.31-0.56$ & 0.40 & 0.39 & 3 \\
\hline Gansu & $0.21-1.13$ & 0.67 & 0.52 & 5 \\
\hline Guangdong & $0.91-2.85$ & 1.88 & 1.61 & 2 \\
\hline Guangxi & $0.38-12.51$ & 3.01 & 1.07 & 5 \\
\hline Guizhou & $0.30-10.05$ & 3.54 & 2.56 & 20 \\
\hline Hebei & $1.07-6.06$ & 2.28 & 1.99 & 15 \\
\hline Heilongjiang & $0.26-0.65$ & 0.39 & 0.37 & 10 \\
\hline Henan & $0.21-6.20$ & 2.24 & 1.52 & 23 \\
\hline Hubei & $1.26-7.93$ & 4.75 & 3.76 & 5 \\
\hline Hunan & $0.27-39.51$ & 8.68 & 2.79 & 9 \\
\hline Jiangsu & $0.43-3.69$ & 1.63 & 1.28 & 6 \\
\hline Jiangxi & $0.31-6.92$ & 2.45 & 1.46 & 7 \\
\hline Jilin & $0.20-1.01$ & 0.37 & 0.29 & 5 \\
\hline Liaoning & $0.04-3.10$ & 0.52 & 0.21 & 9 \\
\hline Inner Mongolia & $0.31-1.81$ & 0.65 & 0.58 & 17 \\
\hline Ningxia & $0.05-1.69$ & 0.82 & 0.45 & 4 \\
\hline Qinghai & - & 0.23 & - & 1 \\
\hline Shaanxi & $0.39-6.53$ & 1.47 & 0.99 & 12 \\
\hline Shandong & $0.58-29.12$ & 5.30 & 2.31 & 20 \\
\hline Shanxi & $0.28-13.65$ & 2.40 & 1.43 & 85 \\
\hline Sichuan & $0.33-18.31$ & 4.21 & 2.35 & 9 \\
\hline Xinjiang & $0.05-0.41$ & 0.28 & 0.22 & 5 \\
\hline Yunnan & $0.38-7.97$ & 2.53 & 1.58 & 8 \\
\hline Total & $0.04-39.51$ & 2.60 & 1.27 & 305 \\
\hline
\end{tabular}

${ }^{a}$ Hong Kong, Macao, Shanghai, Tianjin, Hainan, Xizang, and Zhejiang do not produce raw coal and are not included in the table

\section{Pulverized coal-fired boilers}

No iodine remained in the slag after coal combustion; the distribution of iodine in other by-products is described below.

When ESP was adopted for PM control, the proportion of iodine left over the fly ash was 3.4-7.6\%, averaging $5.5 \%$, which may be attributed to the vaporized iodine condensing and adsorbing onto the fly ash particulates as the temperature of flue gas decreased. Without the FGD system, the proportion of iodine emitted into the atmosphere was $92.4-96.6 \%$, averaging $94.5 \%$, whereas it declined to $85.5 \%$ when wet limestone FGD system was applied; accordingly, $6.9 \%$ of the total iodine was captured by FGD gypsum. Bettinelli et al. (2002) reported that more than $90 \%$ of the total iodine can be removed from flue gas through wet FGD; however, only $6.9 \%$ of the total iodine was captured by FGD gypsum in our study.
This indicates that the iodine captured by FGD gypsum was mainly dissolved in the water; hence, most of the iodine dissolved in the gypsum's interstitial water was re-discharged into the atmosphere when the FGD gypsum was dehydrated through vacuum drying, and vacuum drying of FGD gypsum is widely applied in China.

When the scrubber was applied for PM control, the proportion of iodine that remained in fly ash ranged from 11.1 to $12.7 \%$, averaging $11.9 \%$; meanwhile the share of iodine emitted into the atmosphere ranged from 87.3 to $88.9 \%$, averaging $88.1 \%$.

\section{Grate-fired boilers}

The proportion of iodine that remained in the slag ranged from 1.6 to $2.8 \%$, averaging $2.1 \%$. When cyclone was applied for PM control, the share of iodine captured by fly ash was $2.7-7.2 \%$, averaging $5.4 \%$; accordingly, the proportion of iodine released into the atmosphere accounted for 91.2-95.4\%, averaging $92.7 \%$. When the scrubber was adopted for PM control, $79.2 \%$ of the total iodine was emitted into the atmosphere, indicating that additional $13.5 \%$ of the total iodine was captured by the wet fly ash compared to the amount when cyclones were adopted to control PM emission.

\section{Fluidized bed furnace}

For this type of boiler, the most commonly used PM control device is the scrubber. After coal combustion, the amount of iodine that remained in the slag ranged from 0.8 to $1.2 \%$, averaging $0.9 \%$; the proportion of iodine that was left over the fly ash accounted for 8.6-25.4\%, averaging $14.8 \%$; and accordingly, the share of iodine released into the atmosphere was 78.8-90.6\%, averaging $84.3 \%$.

As mentioned above, iodine was mostly released into the atmosphere during coal combustion. Due to their high chemical activity, organically bounded iodides are not stable in flue gas with high temperature. It is easy for them to be decomposed and hydrolyzed to inorganically bounded iodides. Hence, iodine emitted from coal combustion to the atmosphere might be mainly inorganic forms.

Atmospheric iodine emission factors by sector

Atmospheric iodine emission factor of coal combustion in the power sector

Coal is the leading fuel for power generation in China; coalfired power plants provided $80.4 \%$ of its electricity in 2006 (NBS 2004-2008). According to unpublished data from the China Electricity Corporation Association (CECA), approximately $92 \%$ of boilers in power plants are 
Table 2 Iodine distribution for 1 ton of coal combustion in boilers (mg)

\begin{tabular}{|c|c|c|c|c|c|c|c|}
\hline Sample & $\begin{array}{l}\text { Iodine of } \\
\text { coal }^{\mathrm{a}}\end{array}$ & Iodine into slag ${ }^{\mathrm{a}}$ & $\begin{array}{l}\text { Iodine into } \\
\text { fly } \operatorname{ash}^{\mathrm{a}}\end{array}$ & $\begin{array}{l}\text { Iodine into } \\
\text { gypsum }^{\mathrm{a}, \mathrm{b}}\end{array}$ & $\begin{array}{l}\text { Iodine into } \\
\text { atmosphere }^{\text {a }}\end{array}$ & Boil type & $\begin{array}{l}\text { Emission control } \\
\text { system }\end{array}$ \\
\hline 1 & $1,840(100)$ & $0(0.0)$ & $63(3.4)$ & - & $1,777(96.6)$ & Pulverized coal & ESP \\
\hline 2 & $3,400(100)$ & $0(0.0)$ & $207(6.1)$ & - & $3,193(93.9)$ & Pulverized coal & ESP \\
\hline 3 & $2,250(100)$ & $0(0.0)$ & $92(4.1)$ & - & 2,158 (95.9) & Pulverized coal & ESP \\
\hline 4 & $1,320(100)$ & $0(0.0)$ & $81(6.1)$ & - & $1,239(93.9)$ & Pulverized coal & ESP \\
\hline 5 & $2,580(100)$ & $0(0.0)$ & $196(7.6)$ & $178(6.9)$ & $2,206(85.5)$ & Pulverized coal & ESP and FGD \\
\hline 6 & $860(100)$ & $0(0.0)$ & $109(12.7)$ & - & $751(87.3)$ & Pulverized coal & Scrubber \\
\hline 7 & $850(100)$ & $0(0.0)$ & $94(11.1)$ & - & $756(88.9)$ & Pulverized coal & Scrubber \\
\hline 8 & $1,390(100)$ & $17(1.2)$ & $213(15.3)$ & - & $1,161(83.5)$ & Fluidized bed furnace & Scrubber \\
\hline 9 & $1,290(100)$ & $10(0.8)$ & $111(8.6)$ & - & $1,169(90.6)$ & Fluidized bed furnace & Scrubber \\
\hline 10 & $1,440(100)$ & $12(0.8)$ & $293(20.4)$ & - & $1,135(78.8)$ & Fluidized bed furnace & Scrubber \\
\hline 11 & $710(100)$ & $20(2.8)$ & $128(18.0)$ & - & $562(79.2)$ & Grate firing & Scrubber \\
\hline 12 & $1,030(100)$ & 17 (1.6) & $74(7.2)$ & - & $939(91.2)$ & Grate firing & Cyclone \\
\hline 13 & $1,040(100)$ & $20(1.9)$ & $28(2.7)$ & - & 992 (95.4) & Grate firing & Cyclone \\
\hline 14 & $1,220(100)$ & $28(2.3)$ & $76(6.2)$ & - & $1,116(91.5)$ & Grate firing & Cyclone \\
\hline 15 & $1,180(100)$ & $22(1.9)$ & $63(5.3)$ & & $1,095(92.8)$ & Grate firing & Cyclone \\
\hline
\end{tabular}

${ }^{a}$ The numbers in parentheses are the ratios of partial iodine to the total iodine

b Iodine from the limestone was subtracted from FGD gypsum

pulverized coal-fired boilers, with the remaining being grate-fired boilers (Zhang 2005). For the PM control equipment, approximately $85 \%$ of boilers were installed with ESPs, $12 \%$ with scrubbers, and rest with cyclones (Tsinghua University 2006).

In order to control the atmospheric acid precipitation that originated from coal combustion, coal-fired power plants (the largest $\mathrm{SO}_{2}$ emission source in China) have adopted $\mathrm{SO}_{2}$ emission abatement measures, of which the FGD devices are the preferred one accounted for more than $90 \%$ of the desulfurization units in China (Wang et al. 2007). In the wet limestone FGD system, $\mathrm{SO}_{2}$ is removed from flue gas by absorption into limestone slurry as sulfate, which is in turn extracted from the absorber as gypsum slurry, and finally dewatered.

The penetration rate of the installed capacity of coalfired units that have installed FGD system was $0.8 \%$ in $1998,2 \%$ in $2000,4 \%$ in $2003,12 \%$ in $2005,30 \%$ in 2006, $36.3 \%$ in 2007, $66 \%$ in 2008, and $78 \%$ in 2009 (CPNN 2007; PDO 2010; Wang 1999; Wang et al. 2007; Zhao 2004). Linear interpolation method was used in this study to calculate the penetration rate for the other years.

By referring to the penetration rate of each type of combustors and PM control devices, as well as to the penetration rate of FGD facilities used by the coal-fired power sector in 1995-2009, the atmospheric iodine emission factor can be estimated. Figure 1 shows that the emission factor decreased steadily from $93.3 \%$ in 1995 to $93.0 \%$ in 2003 and recorded a rapid decline to $87.9 \%$ in 2009.
Atmospheric iodine emission factor of coal combustion in the heating supply sector (thermal power sector)

The most commonly used boilers in coal-fired thermal power plants in China include pulverized coal-fired boilers, grate-fired boilers, and fluidized bed furnaces (Xing 2006). In the heating supply sector, the dominant PM control device equipped with pulverized coal-fired boilers and fluidized bed furnace is the scrubber, whereas grate-fired boilers are usually installed with a cyclone. Due to the lack of data for each type of boilers applied in the heating supply sector, the penetration rate of each type of boiler was assumed to be one-third. By referring to Table 2, the atmospheric iodine emission factor for the heating supply sector can be calculated as $88.4 \%$.

\section{Atmospheric iodine emission factor of coal combustion} in the industry sector

According to Tsinghua University (2006), grate-fired boilers account for approximately $92 \%$ of industrial boilers, and the remaining $8 \%$ are fluidized bed furnaces; cyclones and scrubbers are the main equipment types used to control PM, with their penetration rates at 30 and $60 \%$, respectively, with the remaining $10 \%$ being boilers without any control equipment. By referring to Table 2, the atmospheric iodine emission factor for industry sector can be calculated as $89.6 \%$. 


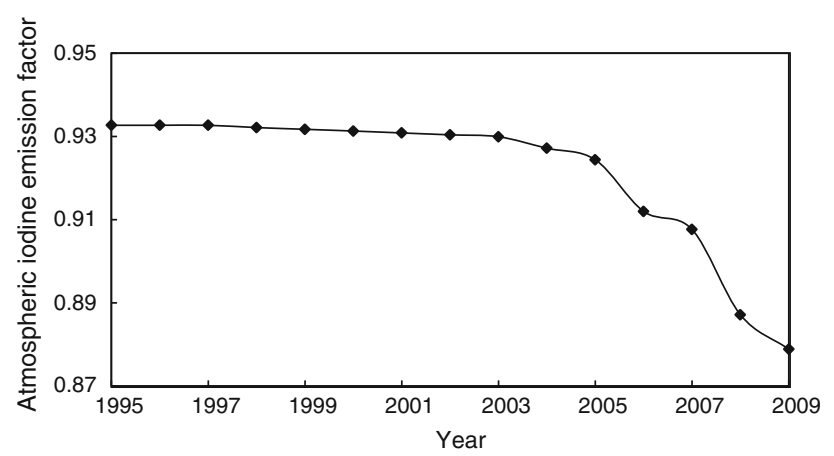

Fig. 1 Atmospheric iodine emission factor of coal combustion of the power sector during 1995-2009

\section{Atmospheric iodine emission factor of coal combustion in smelting and rolling of ferrous metals sector}

In the smelting and rolling of ferrous metals industry, coal consumption has a distinctive character: coal is first transformed into coke, which is used as raw material in metal smelting and as fuel in the rolling process. Under high temperature (i.e., $950-1,050{ }^{\circ} \mathrm{C}$ ), coal is carbonized in the coking chamber and transformed into coke, while raw gas is discharged simultaneously. By spraying ammonia, the hot raw gas is cooled and refined into gas; meanwhile, the by-products including coking tar, raw benzene, raw phenols, and ammonium sulfide are recycled. Due to its high solubility in alkaline media, the iodine of raw gas can be totally absorbed by ammonia, causing the iodine in the feed coal to be transferred to the coke and its by-products. On the basis of the determined iodine content in coke and mass balance, approximately $13.9 \%$ of iodine is transferred into the coke.

Emission control facilities used in the smelting and rolling of ferrous metals sector are similar to those in the industry sector; therefore, the atmospheric iodine emission factor of coke was considered as $89.6 \%$. The atmospheric iodine emission factor of coal consumed in the melting and rolling of ferrous metals sector was then estimated to be $12.5 \%$.

\section{Atmospheric iodine emission factor of coal combustion in the gas production sector}

Coal gas is a flammable gaseous fuel made from coal and supplied to the user via a piped distribution system (Wu et al. 2002). Reacting with the oxidizer $\left(\mathrm{O}_{2}\right.$ and steam) in a gas producer, coal can produce coal gas, a mixture of calorific gases, while waste residue is left behind. On the basis of the determined iodine content in waste residue and mass balance, approximately $9.8 \%$ of iodine is transferred into the waste residue. Coal gas is piped to customers to burn directly without any emission control equipment; hence, the entrained iodine is discharged totally into the atmosphere. Having carbon residual, the waste residue has relatively high heating value. Waste residue can be disposed in two major ways: blended with coal to be combusted in industry boilers, or used to produce internally burnt bricks. The atmospheric iodine emission factor was determined to be $95.8 \%$ in the production of the internal combustion brick. We assumed that the ratio of the two major usage of waste residue was both $50 \%$; thus, the atmospheric iodine emission factor of waste residue was estimated to be $92.7 \%$. The atmospheric iodine emission factor of the gas production sector can then be calculated to be $99.3 \%$.

\section{Atmospheric iodine emission factor of coal combustion in residential consumption sector}

During coal mining, preparation, and transportation, large chunks of coal are broken into smaller pieces of coal and powder. At present, the proportion of powder coal in China is generally up to $60 \%$ when coal is mined mechanically. Powder coal is cheaper (only one-third of the price of a chunk of coal); thus, local residents usually buy powder coal for domestic use (Zhang and Cui 2004; Zheng et al. 2007). When powder coal is directly placed into a stove, the fire is extinguished because of the absence of oxygen, or it can fall directly to the bottom of the stove and fail to combust. Therefore, mix powder coal with adhesive to form briquettes is necessary for effective burning. Owing to its high viscosity, good refractoriness, and economy, clay from B Horizon of soil is favored and adopted widely as the preferred adhesive for making briquettes. The large size of briquettes can prevent the leakage and loss of powder coal, and ensures that there is more space between fuel pieces, thereby yielding higher combustion efficiency (Chen et al. 2004; Wu et al. 2004; Zheng et al. 2007).

Residential briquettes have spread rapidly in China, with penetration rate of $80 \%$; the most common type used in urban areas is the honeycomb briquette (Cheng 1998; Tian 2004). Chinese rural residents usually mix powder coal with clay in order to make coal-clay (a type of briquette) (Wu et al. 2004), which has a penetration rate similar to that of honeycomb briquette of $80 \%$. Hence, only $20 \%$ of coal is combusted directly in Chinese residential consumption.

The iodine distribution of coal combusted in residential stoves is shown in Table 3. When coal-clay is combusted, the proportion of iodine discharged to the slag is $1.7-3.8 \%$, averaging $2.6 \%$, whereas that emitted into the atmosphere is $96.2-98.3 \%$, averaging $97.4 \%$. When honeycomb is combusted, the proportion of iodine discharged to the slag is $0.5-1.1 \%$, averaging $0.8 \%$, and the remaining percentage is emitted to the atmosphere. When lump coal is combusted, 2.1-3.7 \% of iodine is emitted to cinder, averaging $2.5 \%$, and the rest is released to the atmosphere.

Excessive quantity of adhesive applied to make a briquette seriously affects the heating value of coal-clay or honeycomb briquette, whereas insufficient quantity of 
binder may result in low mechanical strength of briquette. According to our investigation, the usual ratio of clay in a briquette is approximately $30 \%$ (Wu et al. 2004).

In this research, the ratio of clay in briquette adopted was $30 \%$, and the iodine content of Chinese soil background value $\left(2.38 \mathrm{mg} \mathrm{kg}^{-1}\right)$ was considered to be the iodine content of clay for making briquettes (CNEMC 1990). Based on the average iodine content of Chinese coals in each year, the penetration rates of coal-clay, honeycomb briquette, and coal in residential coal consumption are 40,40 , and $20 \%$, respectively. The atmospheric iodine emission of coal combustion in residential sector consumption can be calculated, as shown in Fig. 2: increasing from $128.7 \%$ in 1995 to $136.4 \%$ in 2009 , up by $0.5 \%$ annually.

\section{Atmospheric iodine emission factor of coal combustion} in other sectors, such as farming, forestry, fishery, animal husbandry, mining and quarrying, manufacturing, construction, and transportation

These sectors mainly use coal to provide heat source for production and living. Most boilers have capacities lower than 20 tons $\mathrm{h}^{-1}$, with the predominant type being the grate-fired boiler (Wang et al. 2000). The atmospheric iodine emission factor of coal combustion in these sectors adopts that of industrial grate-fired boilers, which is $89.2 \%$.

Impact of coal washing on the atmospheric iodine emission factor of coal combustion

Owing to its economic and environmental significance, coal washing has experienced a continuous increase since the 1980s, with the tonnage of raw coal being washed recorded to have increased from $120 \mathrm{Mt}$ in 1981 to $1,100 \mathrm{Mt}$ in 2007 (Wu et al. 2006; Wu 2009). However, coal slurry and

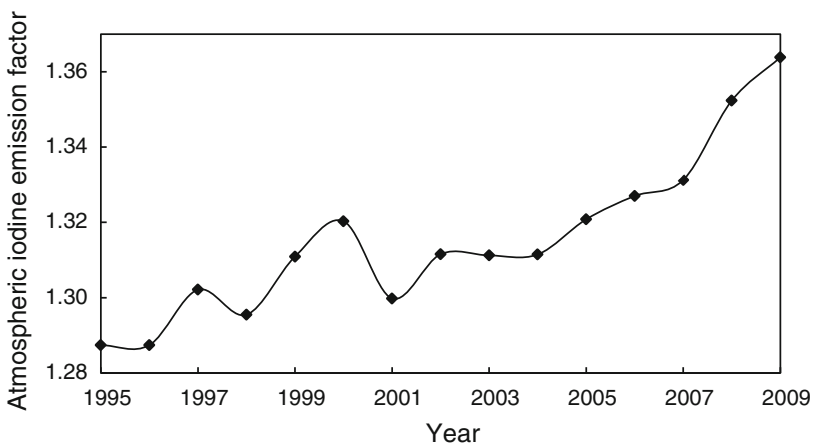

Fig. 2 Atmospheric iodine emission factor of coal combustion in residential sector consumption during 1995-2009

washery rejects, as well as the by-products of coal washing, are not discarded in China. Due to fuel supply shortage, fuels with low heat value are considered to be precious resources, and the Chinese government has given great importance to and strongly supports the utilization of coal slurry and washery rejects to generate electricity, produce cement, and make bricks (Gao and Ma 2005). Thus, the effect of iodine removal by coal washing was neglected in this study.

Coal consumption and its distribution in each sector in China

Coal plays a key role in the Chinese energy mix. Based on the calorific value calculation, coal has long accounted for over $70 \%$ of China's total commercial primary energy consumption, and the rate was up to $76.4 \%$ in 2009 (NBS 1998, 2001, 2004-2008, 2010). Coal has been of crucial importance to China's economy, and its consumption has increased sharply with the country's rapid economic expansion. Figure 3 shows that the coal consumption increased from 1,376.8 Mt in 1995 to 2,958.3 Mt in 2009, with annual average increase rate of $8.2 \%$; it increased
Table 3 Iodine distribution for 1 ton of coal-clay, honeycomb briquette, and coal combustion in residential stoves $(\mathrm{mg})$

a The number in parentheses represents the ratio of partial iodine to the total iodine

\begin{tabular}{|c|c|c|c|c|}
\hline Sample & Fuel type & Iodine of fuel ${ }^{\mathrm{a}}$ & Iodine into slag $^{\mathrm{a}}$ & Iodine into atmosphere \\
\hline 1 & Coal-clay & $5,480(100)$ & $132(2.4)$ & $5,348(97.6)$ \\
\hline 2 & Coal-clay & $5,350(100)$ & $144(2.7)$ & $5,206(97.3)$ \\
\hline 3 & Coal-clay & $5,900(100)$ & $227(3.8)$ & $5,673(96.2)$ \\
\hline 4 & Coal-clay & $4,460(100)$ & $76(1.7)$ & 4,384 (98.3) \\
\hline 5 & Coal-clay & $4,770(100)$ & $170(3.6)$ & $4,600(96.4)$ \\
\hline 6 & Honeycomb briquette & $2,820(100)$ & $14(0.5)$ & $2,806(99.5)$ \\
\hline 7 & Honeycomb briquette & $2,930(100)$ & $23(0.8)$ & 2,907 (99.2) \\
\hline 8 & Honeycomb briquette & $1,610(100)$ & $10(0.6)$ & $1,600(99.4)$ \\
\hline 9 & Honeycomb briquette & $3,250(100)$ & $36(1.1)$ & 3,214 (98.9) \\
\hline 10 & Honeycomb briquette & $2,930(100)$ & $23(0.8)$ & 2,907 (99.2) \\
\hline 11 & Coal & $1,590(100)$ & $35(2.1)$ & $1,555(97.8)$ \\
\hline 12 & Coal & $1,620(100)$ & $40(2.5)$ & $1,580(97.5)$ \\
\hline 13 & Coal & $1,720(100)$ & $64(3.7)$ & $1,656(96.3)$ \\
\hline 14 & Coal & $1,350(100)$ & $24(1.8)$ & $1,326(98.2)$ \\
\hline
\end{tabular}


sharply during the period of 2002-2009, with annual average increase rate of up to $16.7 \%$. Coal will continue to dominate China's energy mix in the foreseeable future, with coal consumption in the country likely to exceed 3,500 Mt in 2020, according to the Ministry of Land and Resources of P.R. China (2009).

The high level of coal usage is expected to continue and to grow; what will change is the way in which the coal is utilized. Figure 4 shows the distribution of coal consumption in each sector during 1995-2009 in China.

Annual atmospheric iodine emission flux from coal combustion in China

Based on the coal consumption and atmospheric iodine emission factors of each sector, the atmospheric iodine emission flux of China and the contribution of each sector to atmospheric iodine emission from 1995 to 2009 can be calculated. The result is shown in Fig. 5.

Based on calculation, the atmospheric iodine emission from coal combustion increased from 3,031.1 tons in 1995 to $3,207.5$ tons in 1996; it then decreased gradually until it reached the lowest amount of 2,595.1 tons in 1999. An upward trend was then observed after 2000 , reaching $4,872.6$ tons in 2009. The average annual rate of increase of atmospheric iodine emission from coal combustion throughout the 14 years is $4.3 \%$.

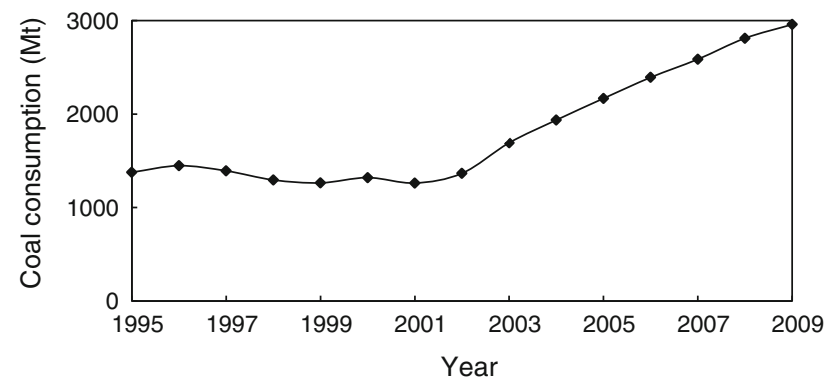

Fig. 3 Coal consumption during 1995-2009 in China
The coal-fired power and industrial sectors, respectively, account for the largest and the second-largest proportions of atmospheric iodine emission from coal combustion in China, contributing over $70 \%$ of the total amount. The share of atmospheric iodine emission from coal-fired power sector increased continuously from $35.7 \%$ in 1995 to $54.3 \%$ in 2009 , recording an average annual rate of $3.7 \%$. The proportion of atmospheric iodine emission from the industrial sector decreased gradually from $35.5 \%$ in 1995 to $26.1 \%$ in 2009 , with an average annual rate of $1.9 \%$. The proportion of atmospheric iodine emission from the residential sector decreased at an average annual rate of $4.6 \%$ from $15.0 \%$ in 1995 to $5.3 \%$ in 2009 , becoming the fourth-largest contributor after ranking third prior to 2004. The share of atmospheric iodine emission from the heating supply sector showed a persistent upward trend from $4.5 \%$ in 1995 to $5.8 \%$ in 2009 , with an average annual rate of $2.1 \%$. In addition, its contribution to atmospheric iodine emission rose from being the fifth-highest contributor in 1995-1998 to ranking fourth in 1999-2004 and third after 2005. Smelting and rolling of ferrous metals and gas production have the least contribution to iodine emission in the air, accounting for a combined proportion of less than $3.2 \%$. The proportion of atmospheric iodine emission from other sectors showed a downward trend from $6.6 \%$ in 1995 to $5.7 \%$ in 2009, with an average annual rate of $1.0 \%$. Furthermore, their contribution to atmospheric iodine emission declined from ranking fourth before 1998 to fifth after 1999.

\section{Conclusion}

The Agency for Toxic Substances and Disease Registry (ATSDR) (2004) estimated that the atmospheric iodine emission from global fossil fuel combustion in 2001 was 500 tons, accounting for approximately $0.05 \%$ of the total atmospheric iodine. Based on this research, the contribution of Chinese coal combustion to global atmospheric iodine was 2,669.2 tons in 2001, indicating that the anthropogenic
Fig. 4 Distribution of coal consumption in each sector during 1995-2009 in China

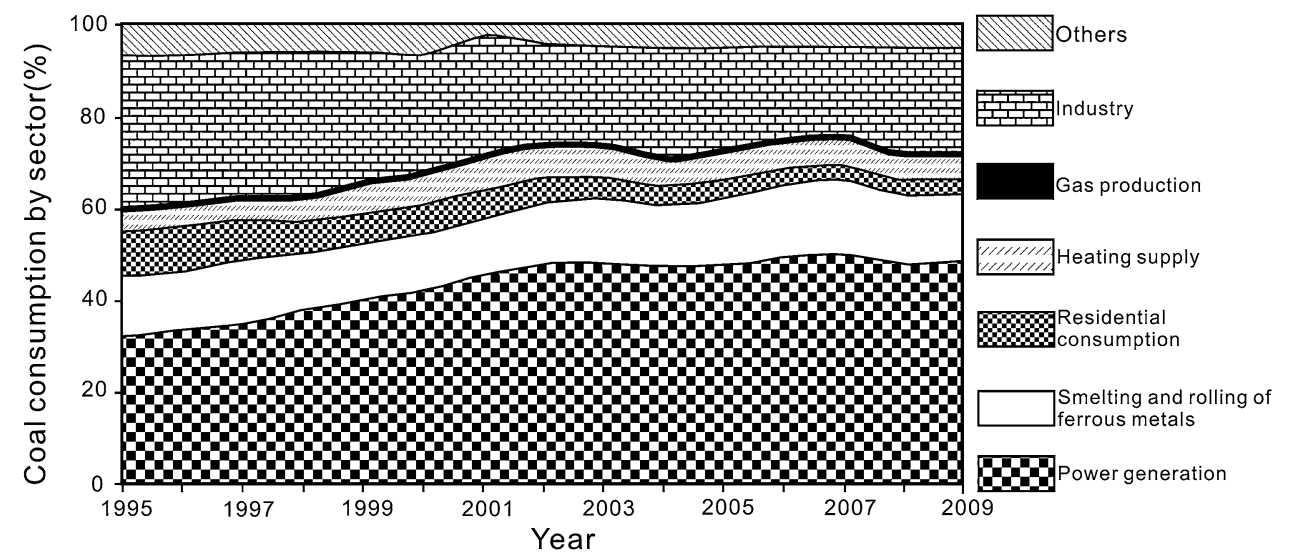


Fig. 5 Atmospheric iodine emission from coal combustion in China and the contribution of each sector from 1995 to 2009

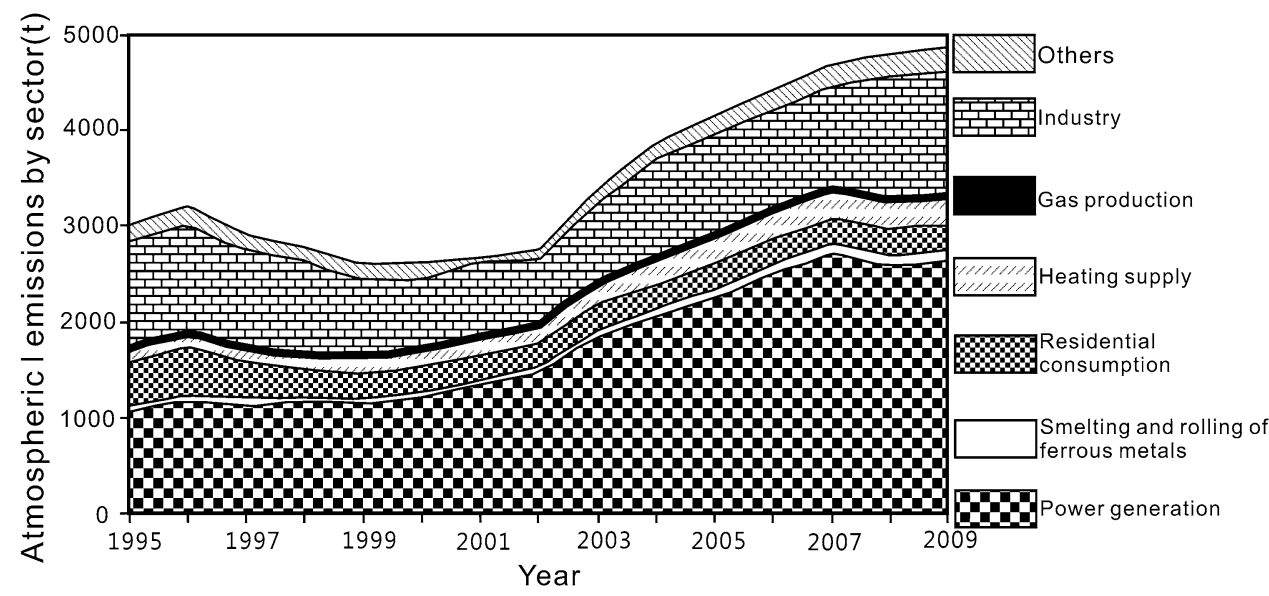

atmospheric iodine emission is significantly underestimated. In 2009, the coal combustion atmospheric iodine emission of China amounted to $0.49 \%$ of the global atmospheric iodine. The atmospheric iodine emission from coal combustion in China is expected to exceed 6,000 tons in 2020, with the contribution rate of global atmospheric iodine at over $0.60 \%$. The iodine emission from coal combustion is concentrated in densely populated areas. It influences the oxidizing ability of atmosphere, forms ultrafine aerosol particles, and enhances depletion of gaseous elemental mercury (Saiz-Lopez et al. 2012). Its environmental and health effects must be given more attention.

Acknowledgments This work was sponsored by the National Natural Science Fund (40973080, 41173115). We show high appreciation for the modification of the English writing by EssayStar Team.

\section{References}

Agency for Toxic Substances and Disease Registry (ATSDR) (2004) Toxicological profile for iodine. http://www.atsdr.cdc.gov/tox profiles/tp158.html

Alicke B, Hebestreit K, Stutz J, Platt U (1999) Iodine oxide in the marine boundary layer. Nature 397:572-573

An D, Duan R, Li P, Wang X (1997) Geographical distribution differences of IDD and endemic fluorosis and their influenced factors in Guizhou Province. Chin J Endem 16(2):86-88

ASTM (1993) ASTM D3174: Standard test method for ash in the analysis sample of coal and coke from coal, ASTM International, West Conshohocken, http://www.astm.org

Baker AR (2005) Marine aerosol iodine chemistry: the importance of soluble organic iodine. Environ Chem 2:295-298

Bertine KK, Goldberg ED (1971) Fossil fuel combustion and the major sedimentary cycle. Science 173:233-235

Bettinelli M, Spezia S, Minoia C, Ronchi A (2002) Determination of chlorine, fluorine, bromine, and iodine in coals with ICP-MS and IC. At Spectrosc 23:105-110

Block C, Dams R (1973) Determination of trace elements in coal by instrumental neutron activation analysis. Anal Chim Acta 68:11-24

British Petroleum (BP) (2010) Statistical review of world energy, London. http://www.bp.com/productlanding.do?categoryId=6929 \& contentId $=7044622$
Carpenter LJ (2003) Iodine in the marine boundary layer. Chem Rev 103:4953-4962

Chameides WL, Davis DD (1980) Iodine: its possible role in tropospheric photochemistry. J Geophys Res Atmos 85:7383-7398

Chen Y, Bi X, Mai B, Sheng G, Fu J (2004) Emission characterization of particulate/gaseous phases and size association for polycyclic aromatic hydrocarbons from residential coal combustion. Fuel 83:781-790

Cheng Y (1998) Study on propaganda and application of clean coal technology in China. China Coal 24:12-16

China National Environmental Monitoring Centre (CNEMC) (1990) The background values of soil elements in China. Chinese Environment Science Press, Beijing

China Power News Network (CPNN) (2007) http://www.cpnn.com. $\mathrm{cn} / \mathrm{hbfb} 2 / \mathrm{hbxw} / 200711140033 . \mathrm{htm}$

Davis D, Crawford J, Liu S, Mckeen S, Bandy A, Thornton D, Rowland F, Blake D (1996) Potential impact of iodine on phys Res Atmos 101:2135-2147

Finkelman RB (2007) Health impacts of coal: facts and fallacies. Ambio 36:103-106

Fuge R (1990) The role of volatility in the distribution of iodine in the secondary environment. Appl Geochem 5:357-360

Fuge R (1996) Geochemistry of iodine in relation to iodine deficiency diseases. In: Appleton JD, Fuge R, McCall GJH (eds) Environmental geochemistry and health. Geological Society Special Publication, London

Fuge R, Johnson CC (1986) The geochemistry of iodine-a review. Environ Geochem Health 8:31-54

Gao X, Ma B (2005) Economic benefits and environmental impacts of different utilization processes of coal reuse. Chin Mining Mag 14(5):45-48

Jenkin ME, Cox RA, Candeland DE (1985) Photochemical aspects of tropospheric iodine behavior. J Atmos Chem 2:359-375

Jones CE, Hornsby KE, Sommariva R, Dunk RM, von Glasow R, McFiggans G, Carpenter LJ (2010) Quantifying the contribution of marine organic gases to atmospheric iodine. Geophys Res Lett 37:L18804. doi:10.1029/2010GL043990

Landsberger S, Vermette VG, Wolfe M, Powell MA (1989) Determination of halogens in coal using thermal and epithermal neutron activation analysis. J Coal Quality 8:95-97

Mahajan AS, Oetjen H, Saiz-Lopez A, Lee JD, McFiggans GB, Plane JMC (2009) Reactive iodine species in a semi-polluted environment. Geophys Res Lett 36:L16803. doi:10.1029/2009GL038018

Ministry of Land and Resources of P. R. China (2009) National mineral resources planning 2008-2015, http://www.mlr.gov.cn/ xwdt/zytz/200901/t20090107_113776.htm tropospheric levels of ozone and other critical oxidants. J Geo- 
National Bureau of Statistics of China (NBS) P. R. China (1998) Chinese energy statistics yearbook (1991-1996). Chinese Statistics Press, Beijing

NBS PR China (2001) Chinese energy statistics yearbook (1997-1999). Chinese Statistics Press, Beijing

NBS PR China (2004-2008) Chinese energy statistics yearbook (2000-2008). Chinese Statistics Press, Beijing

NBS PR China (2010) China energy statistical yearbook (2010). Chinese Statistics Press, Beijing

People's Daily Online (PDO) (2010) http://energy.people.com.cn/ GB/12202378.html

Saiz-Lopez A, Plane JMC (2004) Novel iodine chemistry in the marine boundary layer. Geophys Res Lett 31:L04112. doi: 10.1029/2003GL019215

Saiz-Lopez A, Plane JMC, Baker AR, Carpenter LJ, von Glasow R, Gómez Martín JC, McFiggans G, Saunders RW (2012) Atmospheric chemistry of iodine. Chem Rev 112:1773-1804

SBTS (1996) GB 474-1996, Preparation of coal sample, standardization administration of the People's Republic of China, Beijing, http://www.sac.gov.cn

Solomon S, Garcia RR, Ravishankara AR (1994) On the role of iodine in ozone depletion. J Geophys Res 99:20491-20499

State Bureau of Technical Supervision (SBTS) (1993) GB 481-93, Sampling method of coal sample for production, standardization administration of the People's Republic of China, Beijing, http://www.sac.gov.cn

State Environmental Protection Administration (SEPA), SBTS (1996) GB/T 16157-1996, The determination of particulates and sampling methods of gaseous pollutants emitted from exhaust gas of stationary source, standardization administration of the People's Republic of China, Beijing, http://www.sac.gov.cn

Tian H (2004) Characteristics and development tendency of briquette technology in China. Appl Energy Technol 3:1-3

Tsinghua University (2006) Improve the estimates of anthropogenic mercury emissions in China, Technical report, Tsinghua University, http://www.chem.unep.ch/MERCURY/

Wang Z (1999) Status quo and prospect of environment protection of China's electric power. China electric power 32:46-51

Wang Q, Shen W, Ma Z (2000) Estimation of mercury emission from coal combustion in China. Environ Sci Technol 34:2711-2713
Wang B, Jakson JC, Palmer C, Zheng B, Finkelman RB (2005) Evaluation on determination of iodine in coal by energy dispersive X-ray fluorescence. Geochem J 39:391-394

Wang Z, Pan L, Zhao P, Shi L (2007) Research of the 11th 5-year plan for $\mathrm{SO}_{2}$ pollution control of existing coal fired power plants. Research Environ Sci 20:142-147

Whitehead DC (1984) The distribution and transformation of iodine in the environment. Environ Int 10:321-339

Wu S (2009) Development of coal preparation industry in China in recent 30 years. Coal Processing Compr Util 1:1-4

Wu L, Zhou J, Liu L, Li S (2002) Coal gasification technology advancement. Clean Coal Technol 8:31-34

Wu D, Zheng B, Wang A, Yu G (2004) Fluoride exposure from burning coal-clay in Guizhou Province, China. Fluoride 37:20-27

Wu S, Ye D, Ma J (2006) Development of coal preparation industry in China. Coal Processing Compr Util 5:9-11

Wu D, Deng H, Wang W, Xiao H (2007) Catalytic spectrophotometric determination of iodine in coal by pyrohydrolysis decomposition. Anal Chim Acta 601:183-188

Wu D, Deng H, Zheng B, Wang W, Tang X, Xiao H (2008) Iodine in Chinese coals and its geochemistry during coalification. Appl Geochem 23:2082-2090

Xing P (ed) (2006) Operations and accident treatment of boiler equipment. Chemical Engineering Press, Beijing

Yang X, Bai X, Liu Q, Zhou D, Hu M, Fu Z, Li T, Liao H (2000) Investigation of iodine nutrition status of children in the coalburning endemic fluorosis areas. Chin J Endem 19:239

Zhang Q (2005) Study on regional fine particle emission and simulation in China. Ph.D. Dissertation, Tsinghua University, Beijing

Zhang J, Cui Z (2004) Some comments on the present situation of briquette industries. Coal Eng 10:59-60

Zhao P (2004) Reflection on the problems in coal-burning power plant flue gas desulphurization. Electric Power 37:1-3

Zheng B, Wu D, Wang B, Liu X, Wang M, Wang A, Xiao G, Liu P, Finkelman RB (2007) Fluorosis caused by indoor coal combustion in China: discovery and progress. Environ Geochem Health 29:103-108

Zhu F, Tan J (1988) Selenium, iodine and fluorine in rainwater and dustfall in China. Acta Scientiae Circumstantiae 8:428-437 